\title{
Review \\ Chitosan-Based Nanomaterials as Valuable Sources of Anti-Leishmanial Agents: A Systematic Review
}

\author{
Hamdan I. AlMohammed ${ }^{1}$, Amal Khudair Khalaf ${ }^{2}$, Aishah E. Albalawi ${ }^{3}$, Abdullah D. Alanazi ${ }^{4,5}$ (D), \\ Parastoo Baharvand ${ }^{6}$, Ali Moghaddam ${ }^{7}$ and Hossein Mahmoudvand ${ }^{8, *}$
}

check for

updates

Citation: AlMohammed, H.I.; Khudair Khalaf, A.; E. Albalawi, A.; Alanazi, A.D.; Baharvand, P.; Moghaddam, A.; Mahmoudvand, $\mathrm{H}$. Chitosan-Based Nanomaterials as Valuable Sources of Anti-Leishmanial Agents: A Systematic Review. Nanomaterials 2021, 11, 689. https://doi.org/10.3390/nano11030689

Academic Editor: Shiv Shankar

Received: 29 January 2021

Accepted: 4 March 2021

Published: 10 March 2021

Publisher's Note: MDPI stays neutral with regard to jurisdictional claims in published maps and institutional affiliations.

Copyright: (c) 2021 by the authors. Licensee MDPI, Basel, Switzerland. This article is an open access article distributed under the terms and conditions of the Creative Commons Attribution (CC BY) license (https:/ / creativecommons.org/licenses/by/ $4.0 /)$.
1 Department of Microbiology and Parasitology, Almaarefa University, Riyadh 11597, Saudi Arabia; hamohammedii@mcst.edu.sa

2 Department of Microbiology, College of Medicine, University of Thiqar, Thiqar 0096442, Iraq; amalkhudair111@yahoo.com

3 Faculty of Science, University of Tabuk, Tabuk 47912, Saudi Arabia; ae.Albalawi@ut.edu.sa

4 Department of Biological Science, Faculty of Science and Humanities, Shaqra University, P.O. Box 1040, Ad-Dawadimi 11911, Saudi Arabia; aalanazi@su.edu.sa

5 Department of Medical Laboratory, Alghad International Colleges for Applied Medical Science, Tabuk 47913, Saudi Arabia

6 Department of Social Medicine, School of Medicine, Lorestan University of Medical Sciences, Khorramabad 6813833946, Iran; dr.baharvand@gmail.com

7 Student Research Committee, Lorestan University of Medical Sciences, Khorramabad 6813833946, Iran; alimogh7878@gmail.com

8 Nutritional Health Research Center, Lorestan University of Medical Sciences, Khorramabad 6813833946, Iran

* Correspondence: dmahmodvand@gmail.com

Abstract: Background: The current chemotherapy agents against various forms of leishmaniasis have some problems and side effects, including high toxicity, high cost, and the emergence of resistant strains. Here, we aimed to review the preclinical studies (in vitro and in vivo) on the anti-leishmanial activity of chitosan and chitosan-based particles against Leishmania spp. Methods: This study was conducted based on the 06-PRISMA guidelines and registered in the CAMARADES-NC3Rs Preclinical Systematic Review and Meta-Analysis Facility (SyRF) database. Various English databases such as PubMed, Google Scholar, Web of Science, EBSCO, ScienceDirect, and Scopus were used to find the publications related to the anti-leishmanial effects of chitosan and its derivatives and other pharmaceutical formulations, without a date limitation, to find all the published articles. The keywords included "chitosan", "chitosan nanoparticles", "anti-leishmanial”, "Leishmania", "leishmaniasis", "cutaneous leishmaniasis", "visceral leishmaniasis", "in vitro", and "in vivo". The language for data collection were limited to English. Results: Of 2669 papers, 25 papers, including 7 in vitro (28.0\%), 7 in vivo $(28.0 \%)$, and 11 in vitro/in vivo (44.0\%) studies conducted up to 2020 met the inclusion criteria for discussion in this systematic review. The most common species of Leishmania used in these studies were L. major $(12,48.0 \%)$, L. donovani $(7,28.0 \%)$, and L. amazonensis $(4,16.80 \%)$. In vivo, the most used animals were BALB/c mice $(11,61.1 \%)$ followed by hamsters $(6,33.3 \%)$ and Wistar rats $(1$, $5.5 \%)$, respectively. In vitro, the most used Leishmania form was amastigote $(8,44.4 \%)$, followed by promastigote $(4,22.2 \%)$, and both forms promastigote/amastigote $(6,33.3 \%)$. Conclusion: According to the literature, different types of drugs based on chitosan and their derivatives demonstrated considerable in vitro and in vivo anti-leishmanial activity against various Leishmania spp. Based on the findings of this review study, chitosan and its derivatives could be considered as an alternative and complementary source of valuable components against leishmaniasis with a high safety index. Nevertheless, more investigations are required to elaborate on this result, mainly in clinical settings.

Keywords: cutaneous leishmaniasis; visceral leishmaniasis; promastigote; amastigote; alternative medicine; natural product 


\section{Introduction}

Leishmaniasis is a tropical and subtropical poverty-related disease caused by an intracellular parasite belonging to the genus Leishmania [1]. Humans are generally infected via the bite of a sandfly, mostly Phlebotomus and Lutzomyia, around the world [2]. According to reliable reports, $0.7-1$ million new cases of the disease are notified annually, and 12-15 million people are now infected with the disease in different parts of the world $[3,4]$. Depending on the geographical distribution, various species of Leishmania such as L. tropica, L. major, L. donovani, L. infantum, L. mexicana, L. braziliensis, and L. amazonensis can cause different clinical forms of the disease $[5,6]$. Considering the classification and clinical picture of leishmaniasis in humans, the diseases are divided into four forms of cutaneous (CL), mucocutaneous (NCL), diffuse cutaneous (DCL), and visceral or kala-azar leishmaniasis (VL) $[7,8]$.

There are a number of systemic and local therapeutic strategies for the treatment of various forms of leishmaniasis, including drugs (e.g., pentavalent antimony derivatives such as meglumine antimoniate (Glucantime ${ }^{\circledR}$ ) and sodium stibogluconate (Pentostam ${ }^{\circledR}$ ), miltefosine, pentamidine, amphotericin B (Amp B), and paromomycin), as well as physical treatments (e.g., cryotherapy, surgery, thermotherapy, and laser therapy) [9]. Based on recent studies, the current conventional chemotherapeutics generally have difficulty reaching the target tissues at the applied doses and are also linked to adverse side effects on healthy tissues [10], indicating that the drug delivery systems must improve the efficacy, tolerability, specificity, and therapeutic index of anti-leishmanial drugs. Moreover, unresponsiveness to these anti-leishmanial compounds, even to their higher doses, is regularly reported in some parts of the world $[10,11]$. These limitations motivate researchers to discover an effective alternative agent with low toxicity in natural compounds as a major source of medications with various therapeutics characteristics.

Chitosan (poly-(b-1/4)-2-amino-2-deoxy-D-glucopyranose) is the general name used for a group of natural polysaccharide polymers produced by deacetylation of chitin (Figure 1) [12-14]. In recent years, the use of chitosan and its derivatives has attracted the attention of many researchers in medical and pharmaceutical sciences [15] due to its unique properties such as potent biological properties, low toxicity, biocompatibility, biodegradability, immunomodulatory [16], and anti-cancer, anti-nociceptive, anti-oxidant, anti-inflammatory, and anti-microbial properties $[17,18]$.

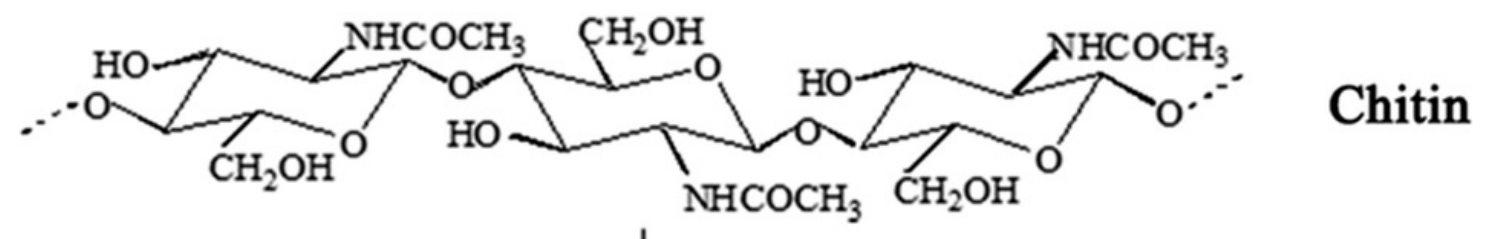

\section{Deacetylation}

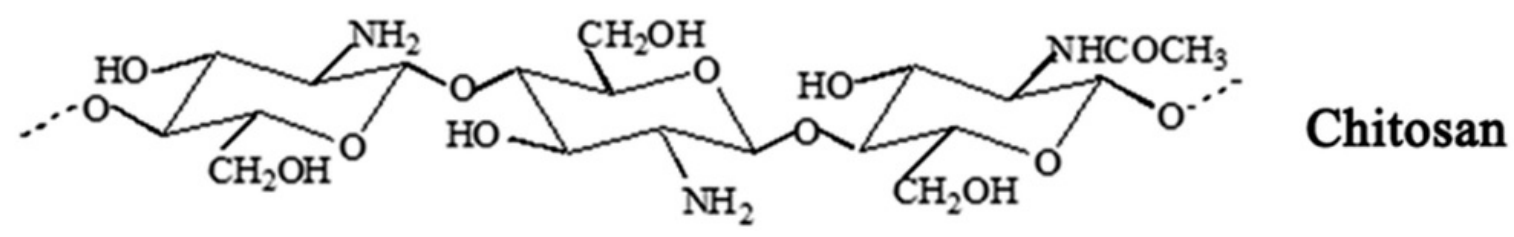

Figure 1. The chemical structure of chitin and chitosan.

Recent studies have demonstrated that the preparation of chitosan-based biomedical drugs such as nanoparticles, hydrogels, coatings, suspensions, powders, membranes, and films can impact the pharmaceutical and biomedical effects of these agents $[19,20]$. Recently, the antimicrobial activities of chitosan and its derivatives have been reported against a 
wide range of pathogenic viruses, bacteria, filamentous and yeast-like fungi [21,22], and helminthic and protozoan parasites [23,24]. Considering the anti-parasitic properties of chitosan and its derivatives, several investigations have demonstrated their potent anti-parasitic effects against some pathogenic strains such as Cryptosporidium spp. [25], Echinococcus granulosus [26], Leishmania spp. [23,24], and Toxoplasma gondii [27,28]. The present study aimed to review the preclinical studies (in vitro and in vivo) on the antileishmanial activity of chitosan and chitosan-based particles against Leishmania spp.

\section{Methods}

\subsection{Database Search}

This investigation was performed based on the 06-PRISMA guideline and registered in the CAMARADES-NC3Rs Preclinical Systematic Review and Meta-Analysis Facility (SyRF) database [29]. English databases, including PubMed, Google Scholar, Web of Science, EBSCO, ScienceDirect, and Scopus, were searched for publications related to anti-leishmanial effects of chitosan and its derivatives and other pharmaceutical formulations without a date limitation to identify all published articles. The keywords included "chitosan", "chitosan nanoparticles", "anti-leishmanial", "Leishmania", "leishmaniasis", "cutaneous leishmaniasis", "visceral leishmaniasis", "in vitro", and "in vivo". Moreover, the language for data collection was limited to English.

\subsection{Quality Assessment and Article Selection}

The studies evaluating the anti-leishmanial effects of chitosan and its derivatives were examined. First, the studies were imported into EndNote X9 (Thomson Reuters, New York, NY, USA) and the duplicates were removed. Afterwards, three authors independently examined the title and abstract of the studies, and the relevant documents about the in vitro and/or in vivo anti-leishmanial effects of chitosan, chitosan derivatives, and chitosanbased nanoparticles were included for further analysis. The same authors carefully read the studies and selected the eligible investigations that adequately met the inclusion criteria. The inclusion criteria were articles evaluating the anti-leishmanial effects of chitosan and its derivatives and emphasizing the design of various forms of nanoparticles containing chitosan and other pharmaceutical formulations against leishmaniasis.

A total of 2669 articles were identified through database searching. Among these articles, 227 articles were removed due to duplication. Of the remaining 2442 articles, 2385 studies were removed due to the inadequate information and the ones in which the abstract was submitted in congresses as preceding papers, conferences, and editorials without full text. One of the main limitations in such studies is the frame of differing access to full texts between different research locations of study, which prevents us from accessing the full-text of some articles. To solve this problem, we searched in various research websites such as ResearchGate and LinkedIn which suggest a choice of direct fulltext request from authors as well as exploring archives of wanted journals, or contacting principal investigator to purchase it if available.

From the remaining 57 articles which were assessed for eligibility, 32 articles were excluded due to some reasons such as inconsistency between methods with results, incorrect interpretation of the results, poor methodology, etc.; whereas 32 articles were finally included in this review (Figure 2).

\subsection{Data Extraction}

Three authors independently extracted information from the selected articles and, if necessary, the differences were resolved upon discussions with the corresponding author. The extracted data included chitosan type, whether it was used in combination or loaded with other drugs, the type of study, animals, doses, time, important results, and references. 


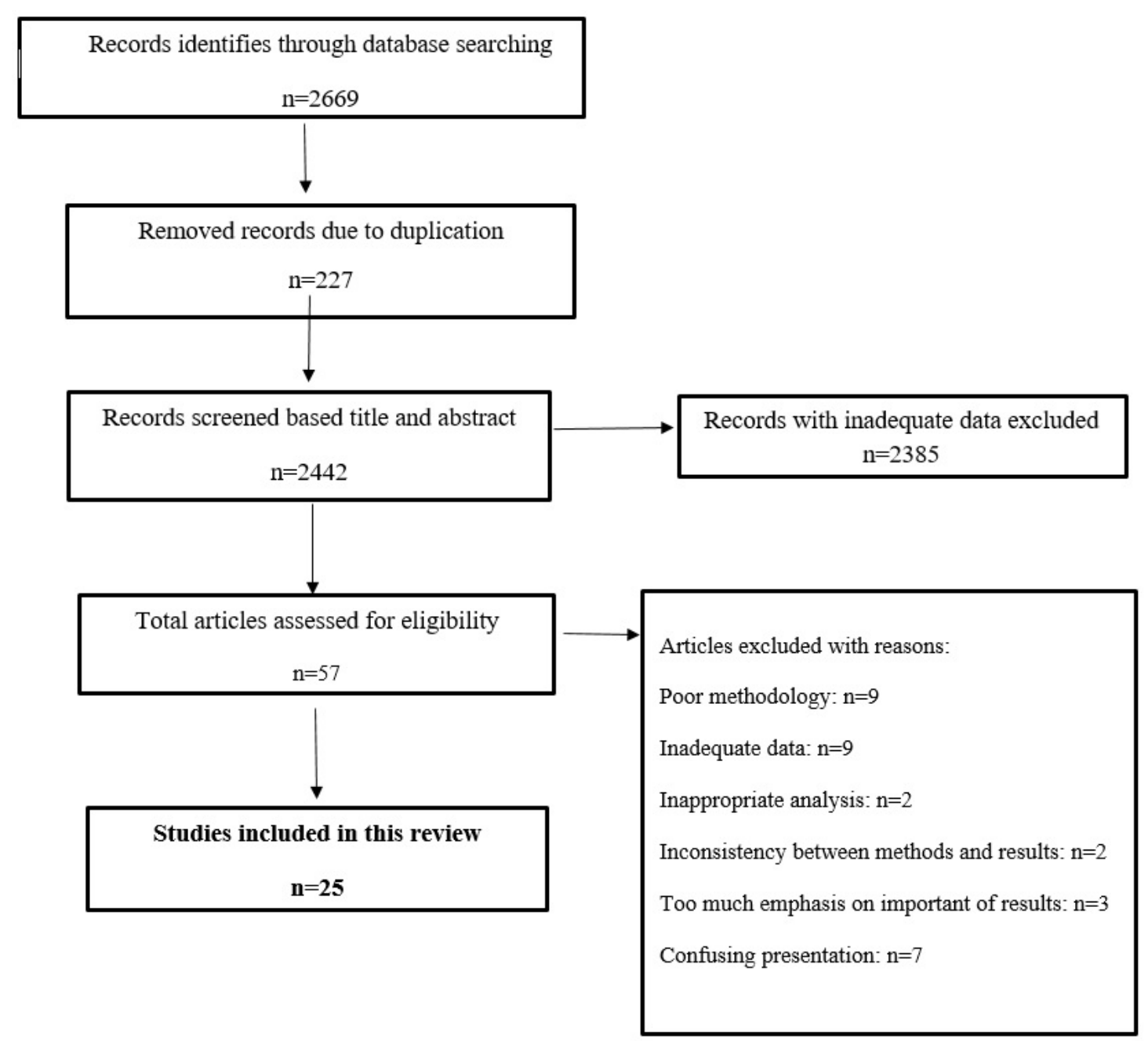

Figure 2. Flowchart describing the study design process.

\section{Results and Discussion}

Chitosan as a natural agent with diverse biological activities is generally found in the shells of crustaceans, such as crab, shrimp, squid pen, and crawfish; however, recent investigations have reported that chitosan can be produced from some fungi [15-17]. Of 2669 papers, 25 papers, including 7 in vitro (28.0\%), 7 in vivo (28.0\%), and 11 in vitro/in vivo (44.0\%) studies conducted up to 2020 met the inclusion criteria for discussion in this systematic review. Totally, the most common species of Leishmania used in these studies were L. major $(12 \%, 48.0 \%)$, L. donovani $(7 \%, 28.0 \%)$, and L. amazonensis $(4 \%, 16.80 \%)$, respectively.

\subsection{Chitosan Treatments In Vitro}

In vitro, the most used Leishmania form was amastigotes $(8 \%, 44.4 \%)$, followed by promastigotes $(4 \%, 22.2 \%)$, and both forms promastigotes/amastigotes $(6 \%, 33.3 \%)$. In terms of the concentrations of chitosan and its formulations, the results demonstrated that, in vitro, they were used in the range of $0.03 \mu \mathrm{g} / \mathrm{mL}$ to $20 \mathrm{mg} / \mathrm{mL}$. The findings demonstrated that the most used synthetic drugs for combination therapy in vitro were amphotericin B $(14 \%$, $70.0 \%)$, followed by miltefosine $(3 \%, 15.0 \%)$ and doxorubicin hydrochloride $(2 \%, 10.0 \%)$. The most common species of Leishmania used in in vitro studies were L. major $(8 \%, 44.4 \%)$, L. donovani $(6 \%, 33.3 \%)$, and L. amazonensis $(3 \%, 16.6 \%)$, respectively (Table 1$)$. 
Table 1. A list of in vitro studies of chitosan and its derivatives as resource for anti-leishmanial agents.

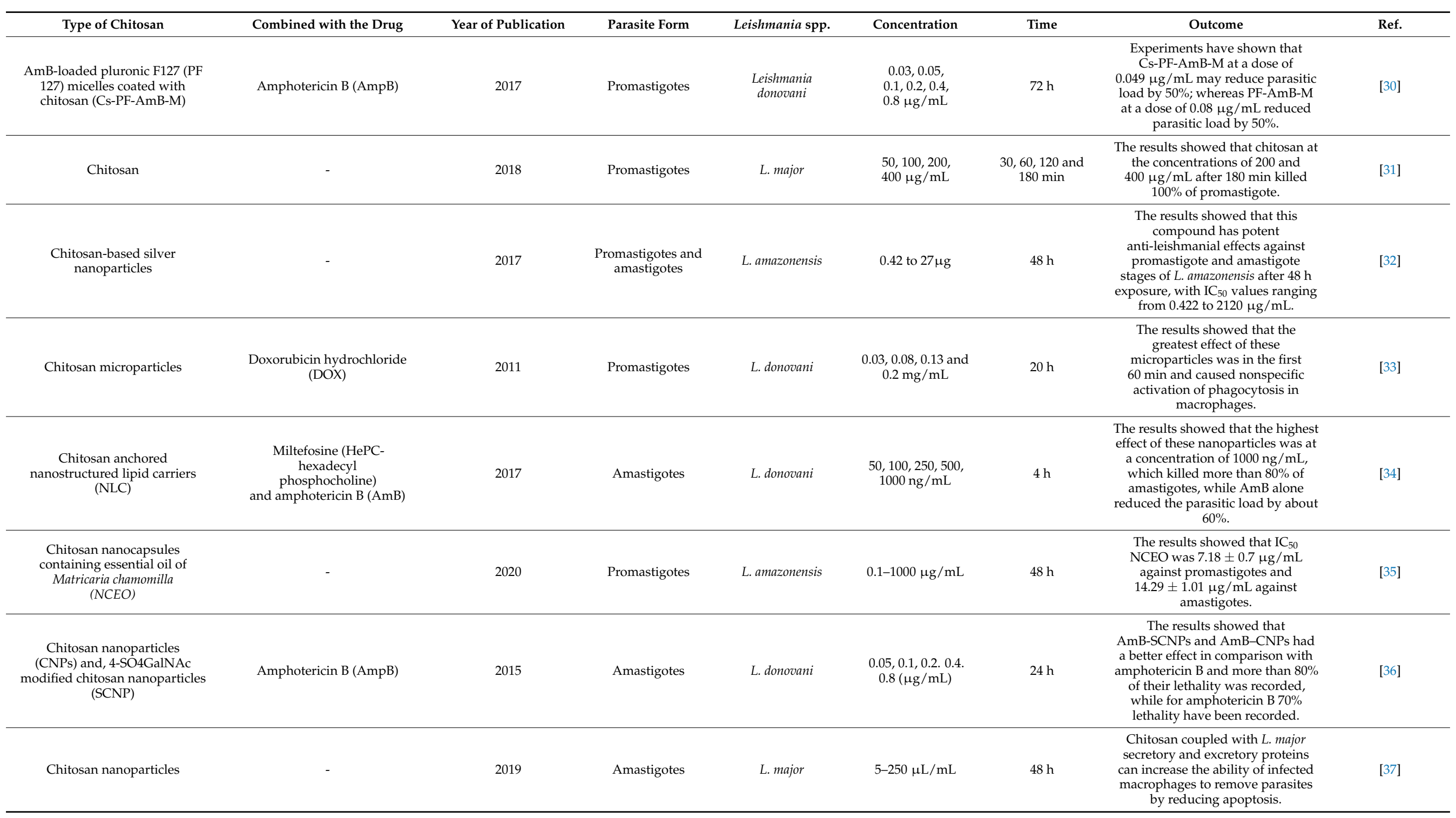


Table 1. Cont.

\begin{tabular}{|c|c|c|c|c|c|c|c|c|}
\hline Type of Chitosan & Combined with the Drug & Year of Publication & Parasite Form & Leishmania spp. & Concentration & Time & Outcome & Ref. \\
\hline Chitosan nanoparticles & Miltefosine & 2020 & $\begin{array}{l}\text { Promastigotes and } \\
\text { amastigotes }\end{array}$ & L. tropica & $100 \mu \mathrm{L} / \mathrm{mL}$ & $72 \mathrm{~h}$ & $\begin{array}{c}\text { The results showed that } \mathrm{IC}_{50} \text { value } \\
\text { for promastigote and amastigote } \\
\text { forms of } L \text {. tropica was } \\
0.07 \pm 0.05 \mu \mathrm{L} / \mathrm{mL} \text { and } \\
0.09 \pm 0.02 \mu \mathrm{L} / \mathrm{mL} \text {, respectively, }\end{array}$ & [38] \\
\hline $\begin{array}{l}\text { Chitosan nanoparticles and } \\
\text { sodium tripolyphosphate (TPP) }\end{array}$ & Amphotericin B (AmB) & 2020 & Amastigotes & $\begin{array}{l}\text { L. major and } L \text {. } \\
\text { mexicana }\end{array}$ & $1 \mathrm{mg} / \mathrm{mL}$ & 7 days & $\begin{array}{c}\text { The results showed that } \mathrm{EC}_{50} \text { value } \\
\text { of AmB-CH-TPP for } L \text {. major and } L \text {. } \\
\text { mexicana amastigotes was } \\
0.14 \pm 0.09 \mu \mathrm{g} / \mathrm{mL} \text { and } 0.5 \pm 0.01 \\
\mu \mathrm{g} / \mathrm{mL} \text {, respectively. }\end{array}$ & [39] \\
\hline $\begin{array}{c}\text { Curcumin-loaded } \\
\text { mannose-functionalized chitosan } \\
\text { nanoparticles } \\
\text { (Cur-MCN) }\end{array}$ & - & 2018 & Amastigotes & L. donovani & $0.05-2.0 \mathrm{mg} / \mathrm{L}$ & $72 \mathrm{~h}$ & $\begin{array}{l}\text { The results showed that Cur-MCN } \\
\text { at the concentration of } \\
0.518 \pm 0.01 \mathrm{mg} / \mathrm{L} \text { reduced } 50 \% \text { of } \\
\text { amastigotes; also, no toxic effect on } \\
\text { macrophages was observed in the } \\
\text { use of Cur-MCN. }\end{array}$ & [41] \\
\hline $\begin{array}{c}\text { Encapsulate } \\
\text { S-nitroso-mercaptosuccinic acid } \\
\text { into chitosan nanoparticles } \\
\text { (NONPs) }\end{array}$ & - & 2019 & $\begin{array}{l}\text { Promastigotes and } \\
\text { amastigotes }\end{array}$ & L. amazonensis & $\begin{array}{c}25,50,75,100,200 \\
400 \mu \mathrm{M}\end{array}$ & $24 \mathrm{~h}$ & $\begin{array}{c}\text { Experiments on amastigotes and } \\
\text { promastigotes of L. amazonensis } \\
\text { showed that NONPs reduced } 65 \% \\
\text { of the parasitic load at a dose of } \\
200 \mu \mathrm{M} \text { and killed } 85 \% \text { of } \\
\text { promastigotes at a dose of } 75 \mu \mathrm{M} \text {. } \\
\text { These nanoparticles also reduced } \\
\text { the number of amastigotes from } \\
8.5 \pm 1.2 \text { in the control group to } \\
4.5 \pm 0.4 \text { per } 300 \text { macrophages and } \\
\text { reduced the infection rate from } \\
76.2 \pm 7.1 \text { to } 63.7 \pm 5.4 .\end{array}$ & [42] \\
\hline $\begin{array}{l}\text { Mannosylated chitosan (MCS) } \\
\text { with dextran } \\
\text { (dex) }\end{array}$ & Paromomycin (PM) & 2019 & Amastigotes & L. major & $\begin{array}{c}5,10,20,40,80 \\
160,320 \mu \mathrm{g} / \mathrm{mL}\end{array}$ & $24,48 \mathrm{~h}$ & $\begin{array}{l}\text { The results showed that this } \\
\text { compound has no cytotoxicity on } \\
\text { macrophages and at a dose of } \\
5 \mu \mathrm{g} / \mathrm{mL} \text { reduced more than } 60 \% \\
\text { of the parasitic load inside } \\
\text { macrophages. }\end{array}$ & [43] \\
\hline
\end{tabular}


Table 1. Cont

\begin{tabular}{|c|c|c|c|c|c|c|c|c|}
\hline Type of Chitosan & Combined with the Drug & Year of Publication & Parasite Form & Leishmania spp. & Concentration & Time & Outcome & Ref. \\
\hline $\begin{array}{l}\text { Nanosized chitosan-betulinic } \\
\text { acid }\end{array}$ & - & 2020 & $\begin{array}{l}\text { Promastigotes and } \\
\text { amastigote }\end{array}$ & L. major & $20 \mu \mathrm{g} / \mathrm{mL}$ & $48 \mathrm{~h}$ & $\begin{array}{l}\text { The results showed that BK20 } \\
(20 \mu \mathrm{g} / \mathrm{mL} \text { ) was effective to kill the } \\
\text { parasite by } 86 \% \text { compared to } \\
\text { negative control group. The } \\
\text { infection rate and the mean } \\
\text { number of amastigotes per each } \\
\text { macrophage were found to be } 73 \% \\
\text { and } 7 \% \text {, respectively. }\end{array}$ & [44] \\
\hline $\begin{array}{l}\text { Oleoyl chitosan and } \\
\alpha \text {-cyclodextrin } \\
(\alpha-C D)\end{array}$ & - & 2019 & Amastigotes & L. major & $100 \mu \mathrm{L}$ & 4 days & $\begin{array}{l}\text { The results showed that the use of } \\
\text { oleoyl chitosan } / \alpha-C D \text { platelets at a } \\
\text { dose of } 60.24 \pm 4.42 \mu \mathrm{gg} / \mathrm{mL} \text { killed } \\
50 \% \text { of amastigotes. }\end{array}$ & [45] \\
\hline $\begin{array}{c}\text { Poly } \\
\text { (isobutylcyano acrylate) } \\
\text { nanoparticles coated with } \\
\text { chitosan (Cs-NPs) }\end{array}$ & $\begin{array}{l}\text { Amphotericin B-deoxycholate } \\
\text { (AmB-DOC) }\end{array}$ & 2019 & $\begin{array}{l}\text { Promastigotes and } \\
\text { amastigote }\end{array}$ & L. major & $20 \mathrm{mg} / \mathrm{mL}$ & $\begin{array}{l}10 \mathrm{~min}, 20 \mathrm{~min}, \\
30 \mathrm{~min}, 1 \mathrm{~h} \text {, or } \\
2 \mathrm{~h}\end{array}$ & $\begin{array}{c}\text { The } \mathrm{IC}_{50} \text { values for } L . \text { major } \\
\text { promastigote and axenic } \\
\text { amastigote forms were } \\
1.14 \pm 0.11 \mu \mathrm{m} / \mathrm{mL} \text { and } 0.53 \pm 0.07 \\
\mu \mathrm{g} / \mathrm{mL} \text {, respectively. }\end{array}$ & [46] \\
\hline $\begin{array}{l}\text { Sodium alginate-glycol chitosan } \\
\text { stearate nanoparticles } \\
\text { (SA-GCS-NP) }\end{array}$ & Amphotericin B (AmB) & 2015 & Amastigotes & L. donovani & $10 \mathrm{ng} / \mathrm{mL}$ & $48 \mathrm{~h}$ & $\begin{array}{c}\text { The IC } \text { I }_{50} \text { values of } \\
\text { AmB-SAGCS-NP and AmB for } \\
\text { amastigotes of } L \text {. donovani were } \\
0.128 \pm 0.024 \mu \mathrm{g} / \mathrm{mL} \text { and } \\
0.214 \pm 0.06 \mu \mathrm{g} / \mathrm{mL} \text {, respectively. }\end{array}$ & [47] \\
\hline
\end{tabular}


The results exhibited that the most used in vitro screening strategy to check the antileishmanial effects of chitosan and its derivatives were the intracellular living amastigote assay, followed by the extracellular promastigote assay. Now, various in vitro systems are used in the evaluation of agents, which show direct toxic action on the parasite [48]; however, for some agents that act through their metabolites and/or host defense system, it does not seem like a good option [49]. Some in vitro screening studies target the promastigote forms of Leishmania because of the simplicity of the cultivation and handling of parasites, the short time required and the low cost [50]; nevertheless, because of some weaknesses, for example, the lack of host cells in this method and the presence of this parasitic form in the invertebrate vector, it is not considered a reliable target to test anti-leishmanial compounds [51]. The use of intracellular amastigote forms in the in vitro system is also well-known as a more clinically relevant model for the assessment of anti-leishmanial compounds due to having some unique features such as acquiring important cell-health information, low cost, and no need for secondary assays [52,53].

Previously, Mohebali et al. [31] have reported that the chitosan at the doses of 100, 200 and $400 \mu \mathrm{g} / \mathrm{mL}$ completely killed the L. major promastigotes in vitro. In another in vitro study conducted by Feizabadi et al. [37], the results showed that chitosan coupled with L. major secretory and excretory proteins can increase the ability of infected macrophages to remove parasites by reducing apoptosis. Riberio et al. (2014) have reported that chitosan nanoparticles combined with $\mathrm{AmpB}$ significantly reduced the lesion size and parasite burden in all the evaluated organs of mice infected with L. amazonensis. They concluded that this compound controls leishmaniasis by increasing the cytokines of IFN- $\gamma$, IL-12, IL-4, and IL-10 in the infected mice [54].

\subsection{Chitosan Treatments In Vivo}

The obtained results showed that the most used animals in vivo were BALB/C mice $(11 \%, 61.1 \%)$ followed by hamsters $(6 \%, 33.3 \%)$ and Wistar rats $(1 \%, 5.5 \%)$. In terms of the concentrations of chitosan and its formulations, the results demonstrated that, in vivo, they were used in the range of $0.005 \mathrm{mg} / \mathrm{kg}$ to $500 \mathrm{mg} / \mathrm{kg}$. The most common species of Leishmania used in in vitro studies were L. major (9\%, 44.4\%), followed by L. donovani (7\%, $33.3 \%$ ) (Table 2). 
Table 2. A list of in vivo studies of chitosan and its derivatives as resources for anti-leishmanial agents.

\begin{tabular}{|c|c|c|c|c|c|c|c|c|c|c|}
\hline Type of Chitosan & $\begin{array}{l}\text { Combined with } \\
\text { the Drug }\end{array}$ & Method & Administration & Animal & $\begin{array}{l}\text { Leishmania } \\
\text { spp. }\end{array}$ & Dose & Time & Outcome & $\begin{array}{c}\text { Year of } \\
\text { Publication }\end{array}$ & Ref. \\
\hline $\begin{array}{l}\text { AmB-loaded pluronic F127 } \\
\text { (PF 127) micelles coated } \\
\text { with chitosan } \\
\text { (Cs-PF-AmB-M) }\end{array}$ & $\begin{array}{l}\text { Amphotericin B } \\
\text { (AmB) }\end{array}$ & $\begin{array}{l}\text { Film hydration } \\
\text { method }\end{array}$ & Intraperitoneal & $\begin{array}{l}\text { Syrian golden } \\
\text { hamster }\end{array}$ & $\begin{array}{l}\text { Leishmania } \\
\text { donovani }\end{array}$ & $1 \mathrm{mg} / \mathrm{kg}$ & 5 days & $\begin{array}{l}\text { The results showed that } \\
\text { Cs-PF-AmB-M and PF-AmB-M } \\
\text { significantly reduced the parasite } \\
\text { load; also, the number of } \\
\text { amastigotes was significantly } \\
\text { reduced by } 52.67 \pm 17.24 \text {. }\end{array}$ & 2017 & {$[30]$} \\
\hline Chitosan & - & - & Topically & BALB/c mice & Leishmania major & $\begin{array}{l}200,400 \\
\mu \mathrm{g} / \mathrm{mL}\end{array}$ & 28 days & $\begin{array}{l}\text { Chitosan reduced the size of the } \\
\text { lesion from } 10.7 \pm 3.24 \mathrm{~mm} \text { in the } \\
\text { control group to } 1.05 \pm 1.02 \mathrm{~mm} \\
\text { on day } 28 \text { at a dose of } 400 \mu \mathrm{gg} / \mathrm{mL} \text {. }\end{array}$ & 2018 & [31] \\
\hline Chitosan microparticles & $\begin{array}{l}\text { Doxorubicin } \\
\text { hydrochloride } \\
\text { (DOX) }\end{array}$ & - & Intraperitoneal & $\begin{array}{l}\text { Golden } \\
\text { hamsters }\end{array}$ & $\begin{array}{l}\text { Leishmania } \\
\text { donovani }\end{array}$ & $500 \mathrm{mg} / \mathrm{kg}$ & 7 days & $\begin{array}{l}\text { The results showed that this } \\
\text { compound killed } 78.2 \pm 10.4 \% \text { of } \\
\text { amastigotes. }\end{array}$ & 2011 & [33] \\
\hline $\begin{array}{l}\text { Chitosan anchored } \\
\text { nanostructured lipid } \\
\text { carriers (NLC) }\end{array}$ & $\begin{array}{c}\text { Miltefosine } \\
\text { (HePC- } \\
\text { hexadecyl } \\
\text { phosphocholine) } \\
\text { and amphotericin } \\
\text { B (AmB) }\end{array}$ & - & Intravenous & Naive hamsters & $\begin{array}{l}\text { Leishmania } \\
\text { donovani }\end{array}$ & $1 \mathrm{mg} / \mathrm{kg}$ & 5 days & $\begin{array}{l}\text { The results showed that } \\
\text { HePC-AmB-CNLCs could reduce } \\
\text { the parasitic load by } 88.14 \pm 4.12 \% \text {, } \\
\text { while tween } 80 \text {-AmB-CNLCs and } \\
\text { AmB reduced the parasite load by } \\
70.91 \pm 3.5 \% \text { and } 53.26 \pm 2.5 \% \text {, } \\
\text { respectively. }\end{array}$ & 2017 & [34] \\
\hline $\begin{array}{l}\text { Chitosan nanocapsule } \\
\text { (CNC) }\end{array}$ & Amphotericin B & $\begin{array}{l}\text { Emulsification } \\
\text { n-solvent } \\
\text { evaporation }\end{array}$ & Intraperitoneal & $\begin{array}{l}\text { Syrian golden } \\
\text { hamsters }\end{array}$ & $\begin{array}{l}\text { Leishmania } \\
\text { donovani }\end{array}$ & $\begin{array}{l}1 \mathrm{mg} \text { of } \\
\mathrm{drug} / \mathrm{kg}\end{array}$ & 30 days & $\begin{array}{l}\text { The results showed that this } \\
\text { compound killed } 86.1 \pm 2.08 \% \text { of } \\
\text { Leishmania amastigotes. }\end{array}$ & 2013 & [55] \\
\hline Chitosan nanoparticles & - & $\begin{array}{c}\text { Ionotropic } \\
\text { gelation process }\end{array}$ & Subcutaneously & $\mathrm{BALB} / \mathrm{c}$ mice & $\begin{array}{l}\text { Leishmania } \\
\text { major }\end{array}$ & $5 \mu \mathrm{g} / 50 \mu \mathrm{L}$ & 3 weeks & $\begin{array}{l}\text { The results showed that injection } \\
\text { of this compound in BALB/c mice } \\
\text { could activate TH1 cells and IgG2a } \\
\text { and eradicate Leishmania with } \\
\text { cell-mediated immunity. }\end{array}$ & 2011 & [56] \\
\hline Chitosan nanoparticles & $\begin{array}{l}\text { Amphotericin B } \\
\text { (AmpB) }\end{array}$ & $\begin{array}{l}\text { Polyelectrolyte } \\
\text { complexes } \\
\text { technique }\end{array}$ & Intravenous & BALB/c mice & $\begin{array}{l}\text { Leishmania } \\
\text { amazonensis }\end{array}$ & $100 \mu \mathrm{L} / \mathrm{kg}$ & 10 days & $\begin{array}{l}\text { The results showed that the } \\
\text { combined use of chitosan and } \\
\text { chondroitin sulfate nanoparticles } \\
\text { with amphotericin B can } \\
\text { significantly reduce the lesion size } \\
\text { and parasitic load and also provide } \\
\text { higher levels of IFN- } \gamma \text { and IL- } 12 \text {. }\end{array}$ & 2014 & [54] \\
\hline $\begin{array}{l}\text { Chitosan nanoparticles } \\
\text { (CNPs) and, 4-SO4GalNAc } \\
\text { modified chitosan } \\
\text { nanoparticles } \\
\text { (SCNP) }\end{array}$ & $\begin{array}{l}\text { Amphotericin B } \\
\text { (AmpB) }\end{array}$ & Ionic gelation & Intravenous & Wistar rats & $\begin{array}{l}\text { Leishmania } \\
\text { donovani }\end{array}$ & $1 \mathrm{mg} / \mathrm{kg}$ & $\begin{array}{l}0.5 \\
1,2,4,6 \text { and } \\
24 \mathrm{~h}\end{array}$ & $\begin{array}{l}\text { The results showed that the use of } \\
\text { AmB-SCNPs reduced the load of } \\
\text { parasites in the spleen by } \\
75.30 \pm 3.76 \% \text {, but the use of } \\
\text { AmB-CNPs and amphotericin B } \\
\text { alone kills } 63.89 \pm 3.44 \% \text { and } \\
47.56 \pm 2.37 \% \text { of parasites. }\end{array}$ & 2015 & [36] \\
\hline
\end{tabular}


Table 2. Cont.

\begin{tabular}{|c|c|c|c|c|c|c|c|c|c|c|}
\hline Type of Chitosan & $\begin{array}{l}\text { Combined with } \\
\text { the Drug }\end{array}$ & Method & Administration & Animal & $\begin{array}{l}\text { Leishmania } \\
\text { spp. }\end{array}$ & Dose & Time & Outcome & $\begin{array}{c}\text { Year of } \\
\text { Publication }\end{array}$ & Ref. \\
\hline $\begin{array}{l}\text { Chitosan nanoparticles and } \\
\text { sodium tripolyphosphate } \\
\text { (TPP) }\end{array}$ & $\begin{array}{c}\text { Amphotericin B } \\
\text { (AmB) }\end{array}$ & $\begin{array}{l}\text { Dextran } \\
\text { sulphate } \\
\text { aqueous } \\
\text { solution }\end{array}$ & Intravenous & BALB/c mice & Leishmania major & $\begin{array}{l}1.25,2.5, \\
5 \mathrm{mg} / \mathrm{kg}\end{array}$ & 10 days & $\begin{array}{l}\text { AmB-CH-TPP at a dose of } 5 \\
\mathrm{mg} / \mathrm{kg} \text { reduced the size of the } \\
\text { lesion by } 83 \% \text { and also reduce the } \\
\text { parasitic load by } 99 \% \text {, but CH-TPP } \\
\text { only reduced } 35 \% \text { of the lesion size } \\
\text { and } 65 \% \text { of parasitic load. }\end{array}$ & 2020 & [39] \\
\hline Chitosan platelets & $\begin{array}{l}\text { Amphotericin } \\
\text { B-deoxycholate }\end{array}$ & - & Intralesional & BALB /c mice & Leishmania major & $100 \mu \mathrm{L} / \mathrm{kg}$ & 13 days & $\begin{array}{l}\text { The results showed that the use of } \\
\text { AmB-DOC and the chitosan } \\
\text { platelets caused thickening and } \\
\text { dry scales on the lesion, which } \\
\text { indicated improvement; } \\
\text { granuloma spread in these mice is } \\
\text { more limited and the number of } \\
\text { infected macrophages is less than } \\
\text { the use of AmB-DOC. }\end{array}$ & 2019 & [45] \\
\hline $\begin{array}{l}\text { Curcumin-loaded } \\
\text { mannose-functionalized } \\
\text { chitosan nanoparticles } \\
\text { (Cur-MCN) }\end{array}$ & - & - & Intraperitoneal & Hamster & $\begin{array}{l}\text { Leishmania } \\
\text { donovani }\end{array}$ & $50 \mathrm{mg} / \mathrm{kg}$ & 5 days & $\begin{array}{c}\text { The results showed that Cur-MCN } \\
\text { have more anti-leishmaniasis } \\
\text { properties than curcumin alone } \\
\text { and are also more efficient at drug } \\
\text { delivery than Cur-CN } \\
\text { (curcumin-loaded unconjugated } \\
\text { chitosan nanoparticles). Cur-MCN } \\
\text { were able to reduce the parasitic } \\
\text { load in the spleen by } 94.20 \% \text { and } \\
\text { the number of amastigotes from } \\
1647 \pm 125.2 \text { in the control group } \\
\text { to } 112 \pm 32.2 \text { per } 500 \text { macrophages. }\end{array}$ & 2018 & [41] \\
\hline Nano chitosan & Amphotericin B & - & Intralesional & BALB/c mice & Leishmania major & $\begin{array}{l}5,7,10 \\
\mathrm{mg} / \mathrm{kg}\end{array}$ & 3 weeks & $\begin{array}{l}\text { The results showed that this } \\
\text { compound improved the lesion } \\
\text { and reduce its diameter to } 0 \mathrm{~mm} \\
\text { and killed } 81 \% \text { of amastigotes; } \\
\text { additionally, no mortality was } \\
\text { reported in mice after using this } \\
\text { compound; while using } \\
\text { amphotericin } \mathrm{B} \text { alone, } 10 \% \text { of mice } \\
\text { died, and no toxicity or side effects } \\
\text { were reported. }\end{array}$ & 2018 & [57] \\
\hline $\begin{array}{c}\text { Poly } \\
\text { (isobutylcyano acrylate) } \\
\text { nanoparticles coated with } \\
\text { chitosan (Cs-NPs) }\end{array}$ & $\begin{array}{l}\text { Amphotericin } \\
\text { B-deoxycholate } \\
\text { (AmB-DOC) }\end{array}$ & - & Topically & BALB/c mice & Leishmania major & $100 \mu \mathrm{L} / \mathrm{kg}$ & 13 days & $\begin{array}{l}\text { The results showed that topical } \\
\text { application of this compound with } \\
\text { or without AmB-DOC on the skin } \\
\text { of } L \text {. major mice could cause a } \\
\text { slight improvement of the CL } \\
\text { lesion; also, the collected skin } \\
\text { samples showed that this } \\
\text { combination reduces the parasitic } \\
\text { load. }\end{array}$ & 2019 & [46] \\
\hline
\end{tabular}


Table 2. Cont.

\begin{tabular}{|c|c|c|c|c|c|c|c|c|c|c|}
\hline Type of Chitosan & $\begin{array}{l}\text { Combined with } \\
\text { the Drug }\end{array}$ & Method & Administration & Animal & $\begin{array}{l}\text { Leishmania } \\
\text { spp. }\end{array}$ & Dose & Time & Outcome & $\begin{array}{c}\text { Year of } \\
\text { Publication }\end{array}$ & Ref. \\
\hline $\begin{array}{l}\text { Sodium alginate-glycol } \\
\text { chitosan stearate } \\
\text { nanoparticles } \\
\text { (SA-GCS-NP) }\end{array}$ & $\begin{array}{l}\text { Amphotericin B } \\
\text { (AmB) }\end{array}$ & $\begin{array}{l}\text { Ionotropic } \\
\text { complexation } \\
\text { method }\end{array}$ & Intraperitoneally & $\begin{array}{l}\text { Syrian golden } \\
\text { hamsters }\end{array}$ & $\begin{array}{l}\text { Leishmania } \\
\text { donovani }\end{array}$ & $\begin{array}{c}5,10 \\
20 \mathrm{mg} / \mathrm{kg}\end{array}$ & 5 days & $\begin{array}{c}\text { The results showed that } \\
\text { AmB-SAGCS-NP reduced } \\
70.21 \pm 3.46 \% \text { of the parasitic load, } \\
\text { while AmB kills only } \\
53.24 \pm 2.84 \% \text { of amastigotes. }\end{array}$ & 2015 & [47] \\
\hline $\begin{array}{c}\beta \text {-lapachone ( } \beta L P \text { ) in } \\
\text { lecithin-chitosan } \\
\text { nanoparticles (NP) }\end{array}$ & - & - & Topically & BALB/c mice & Leishmania major & $20 \mathrm{mg} / \mathrm{kg}$ & 21 days & $\begin{array}{l}\text { The use of these nanoparticles in } \\
\text { CL reduced the number of } \\
\text { amastigotes from } 46 \text { to } 11 \text { per } \\
100 \text { macrophages; also, these } \\
\text { nanoparticles reduced the size of } \\
\text { the lesion from } 61.2 \pm 21.2 \mathrm{~mm}^{2} \text { to } \\
35.7 \pm 29.4 \mathrm{~mm}^{2} .\end{array}$ & 2015 & [58] \\
\hline $\begin{array}{c}\text { Nanosized } \\
\text { chitosan-betulinic acid }\end{array}$ & - & $\begin{array}{c}\text { Drug } \\
\text { adsorption and } \\
\text { phase } \\
\text { separation }\end{array}$ & Intraperitoneally & BALB/c mice & Leishmania major & $20 \mathrm{mg} / \mathrm{kg}$ & 28 days & $\begin{array}{l}\text { The lesion size in positive control } \\
\text { group (GUL200) was negligibly } \\
\text { decreased to } 1.2 \mathrm{~mm} \text {; also, in } \\
\text { B20 mg/ } / \mathrm{kg} \text { and } \mathrm{K} 12.5 \mathrm{mg} / \mathrm{kg} \\
\text { receiver mice, the lesion size was } \\
\text { slightly decreased, while in the } \\
\text { group of BK20 } \mathrm{mg} / \mathrm{kg} \text {, the lesion } \\
\text { size was considerably decreased } \\
\text { and reached to zero }(p<0.001)\end{array}$ & 2018 & [59] \\
\hline $\begin{array}{l}\text { Chitosan-based } \\
\text { nano-scaffolds }\end{array}$ & - & $\begin{array}{l}\text { Electrospinning } \\
\text { method }\end{array}$ & Topically & BALB/c mice & Leishmania major & $20 \mathrm{wt} \%$ & 28 days & $\begin{array}{l}\text { This compound significantly } \\
\text { reduced skin ulcer diameter } \\
(p=0.000), \text { parasite burden } \\
(p=0.003) \text {, changes in the } \\
\text { epidermis }(p=0.023) \text {, and dermis } \\
(p=0.032) ; \text { indicated significantly } \\
\text { strong effectiveness of the } \\
\text { produced nano-scaffolds against } \\
\text { Leishmania ulcers. }\end{array}$ & 2020 & [44] \\
\hline $\begin{array}{c}\text { N-Palmitoyl-N- } \\
\text { monomethyl-N,N-dimethyl- } \\
\text { N,N,N-trimethyl6-O-glycol } \\
\text { chitosan } \\
\text { nanoparticles (GCPQ) }\end{array}$ & Amphotericin B & - & Orally & BALB/c mice & $\begin{array}{l}\text { Leishmania } \\
\text { infantum }\end{array}$ & $5 \mathrm{mg} / \mathrm{kg}$ & 10 days & $\begin{array}{l}\text { AmB-GCPQ nanoparticles } \\
\text { demonstrated higher efficacy } \\
\text { compared with parenteral } \\
\text { liposomal AmB. }\end{array}$ & 2015 & [60] \\
\hline
\end{tabular}


In vivo assay or using the standardized animal models in laboratories are considered as the best strategies to evaluate the anti-leishmanial drug compounds against various forms of leishmaniasis which has the closest resemblance to the human condition [61]. Although the predictive power of the in vivo assay is not very noticeable, however, the important points in this model are that (i) if a drug is not effective in vivo, there is no need to study further and that (ii) some useful information is obtained about the effective doses as well as the toxicity of the studied drugs [48]. Today, several in vivo experimental models are used to assess and test novel agents against various forms of leishmaniasis, e.g., (i) the BALB/C mice-L. major model considered as a validated model for human CL; (ii) C57BL/6, BALB/C, and CBA/J mice to induce L. amazonensis, L. mexicana infection; (iii) BALB/C mice and Syrian golden hamster as experimental models for L. infantum infection [48,49].

Mohebali et al. [30] have demonstrated that the chitosan at the doses of 100, 200 and $400 \mu \mathrm{g} / \mathrm{mL}$ reduced the size of the lesion from $10.7 \pm 3.24 \mathrm{~mm}$ in the control group to $1.05 \pm 1.02 \mathrm{~mm}$ on day 28 at a dose of $400 \mu \mathrm{g} / \mathrm{mL}$, and also from $6.27 \pm 1.23 \mathrm{~mm}$ to $2.07 \pm 0.87 \mathrm{~mm}$ in the $200 \mu \mathrm{g} / \mathrm{mL}$ concentration in the mice infected with L. major. Mohammadi-Samani et al. [56] showed that superoxide dismutase B1 combined with chitosan nanoparticles is able to promote the immunogenicity to cell-mediated immunity $(\mathrm{T}(\mathrm{H}) 1$ cells producing IgG2a in mice) that is effective in removing of Leishmania parasites and might be considered as a single-dose nanovaccine for leishmaniasis.

\subsection{Treatments Using Chitosan as Vehicle}

Nowadays, it has been demonstrated that chitosan, its derivatives, and chitosanbased nanomaterials are able to possibly remove barriers in the carrying of drugs, thus improving the efficacy of the drug and subsequently the targeted drug therapy [62]. The findings demonstrated that the most used synthetic drugs for combination therapy in vivo and in vitro were amphotericin B (14\%, 70.0\%), followed by miltefosine $(3 \%, 15.0 \%)$ and doxorubicin hydrochloride $(2 \%, 10.0 \%)$. Although most of the studies in this review use chitosan in combination with other drugs, however, chitosan and its derivatives without combination with common drugs have been considered in some studies.

Malli et al. (2019) have also demonstrated that the nanoparticles of poly (isobutylcyanoacrylate) coated with chitosan have potent anti-leishmanial effects on L. major promastigotes through morphological changes such as the aberrant shape and swelling of mitochondria and parasitic vacuoles [45]. In a study conducted by Feizabadi et al. (2019), it has been proven that chitosan combined with L. major secretory and excretory proteins can improve the ability of infected macrophages to remove parasites by decreasing apoptosis [37].

For example, Lima et al. [32] have reported that chitosan-silver nanoparticles have more anti-leishmanial activity than chitosan on L. amazonensis promastigotes with the $\mathrm{IC}_{50}$ values of 1.69 and $7.81 \mu \mathrm{g} / \mathrm{mL}$, respectively. In the study conducted by Seyyed Tabaei et al. [44] have showed that chitosan-polyethylene oxide-berberine nanofibers has potent therapeutic effects on healing of CL induced by L. major in BALAB/C mice through reducing the parasite burden, decreasing the lesion size as well as change in the epidermis and dermis.

In recent years, the anti-parasitic activities of chitosan and its various derivatives / formulations have been studied against several parasitic pathogens such as C. pavum [25], Echinococcus spp. [26], and T. gondii [27,28]. For example, Mammeri et al. (2018) demonstrated that chitosan significantly decreased the viability of Cryptosporidium paroum oocysts by $>95 \%$ after $24 \mathrm{~h}$ of treatment with chitosan mix (C-Mix) and chitosan N-acetyl-D-glucosamine (CNAD). They also reported that C-Mix (34.5\%) and CNAD (56\%) significantly decreased the oocysts shedding by $34.5 \%$ and $56 \%$ in newborn mice infected with cryptosporidiosis, respectively [25]. Torabi et al. (2018) have demonstrated that chitosan-praziquantel and chitosan-albendazole nanoparticles especially in combination at the doses of 1,5 , and $10 \mu \mathrm{g} / \mathrm{mL}$ significantly reduced the viability of microcysts, weight and number of cysts in vitro and in vivo [26]. In the study conducted by Teimouri et al. (2018), it has been proven that low molecular weight chitosan 
nanoparticles completely killed the tachyzoites at the concentration of 500 and 1000 ppm in vitro; they also showed that this compound considerably increased the survival time of infected mice with T. gondii RH strain from 6 to 8 days after infection [27].

\subsection{Possible Antimicrobial Mechanisms of Chitosan}

The precise antimicrobial mechanism of action of chitosan is yet to be fully understood; still, based on the literature, the most likely antimicrobial mechanisms of action of chitosan include the disruption of the cell wall and, consequently, an effect on the membrane's permeability, inhibition of DNA replication, cell death, and bindings to the trace metal elements resulting in toxin production and microbial growth inhibition [63].

Mohammadi-Samani et al. (2011) have reported that chitosan nanoparticles containing Leishmania superoxide dismutase could be considered a nano-vaccine for leishmaniasis eradication by promoting the immune response toward cell-mediated immunity (TH1 cells producing IgG2a in mice) [56].

\subsection{Cytotoxicity Effects of Chitosan}

With respect to the cytotoxic effects of chitosan and its various formulations, Karam et al. (2020) found that chitosan nanocapsules containing the essential oil of Matricaria chamomilla have no significant cytotoxicity against macrophage cells with a $\mathrm{CC}_{50}$ (the $50 \%$ cytotoxic concentration) value of $207.92 \pm 18.53 \mu \mathrm{g} / \mathrm{mL}$ compared to $19.71 \pm 1.73 \mu \mathrm{g} / \mathrm{mL}$ for essential oil alone [35]. Another study conducted by Chaubey et al. (2018) indicated that the mannose-conjugated chitosan nanoparticles of curcumin had no significant cytotoxicity against the J774A.1 macrophage cell line with a $C_{50}$ value of $26 \pm 0.60 \mathrm{mg} / \mathrm{mL}$ [41] Recently, Esfandiari et al. (2019) have reported that paromomycin-loaded mannosylated chitosan nanoparticles had no considerable cytotoxicity against the human monocyte cell line of THP-1 cells with a $\mathrm{CC}_{50}$ value of $3911 \mu \mathrm{g} / \mathrm{mL}$ [43].

\section{Conclusions}

Studies in recent years revealed that chitosan, its derivatives, and chitosan-based nanomaterials are able possibly remove barriers in the carrying of drugs thus improving the efficacy of the drug and subsequently the targeted drug therapy. In the present review, based on the literature, various forms of drugs based on chitosan and their derivatives exhibited significant antileishmanial activity against various Leishmania spp, in vitro and in vivo. The results showed that chitosan and chitosan-based particles could be considered as an alternative and complementary source of valuable components against leishmaniasis with a high safety index. However, more studies are required to elucidate this finding, particularly in clinical settings.

Author Contributions: Conceptualization, H.I.A. and H.M.; methodology, A.K.K., A.E.A., and A.D.A.; software, P.B. and A.M.; validation, A.K.K., A.E.A., A.D.A., H.I.A., H.M., A.M. and P.B.; formal analysis, A.M. and P.B.; investigation, A.M. and H.M.; data curation, P.B.; writing-original draft preparation, H.M. and P.B.; writing-review and editing A.K.K., A.E.A., A.D.A., H.I.A., and A.M.; supervision, H.M. All authors have read and agreed to the published version of the manuscript.

Funding: Not applicable.to those who have contributed substantially to the work reported.

Institutional Review Board Statement: Not applicable.

Informed Consent Statement: Not applicable.

Data Availability Statement: All data generated or analyzed during this study are included in this published article.

Conflicts of Interest: The authors declare that they have no competing interests. 


\section{References}

1. Torres-Guerrero, E.; Quintanilla-Cedillo, M.R.; Ruiz-Esmenjaud, J.; Arenas, R. Leishmaniasis: A review. F1000Research 2017, 6, 750. [CrossRef] [PubMed]

2. Alvar, J.; Vélez, I.D.; Bern, C.; Herrero, M.; Desjeux, P.; Cano, J.; Jannin, J.; den Boer, M.; WHO Leishmaniasis Control Team. Leishmaniasis Worldwide and Global Estimates of Its Incidence. PLoS ONE 2012, 7, e35671. [CrossRef] [PubMed]

3. World Health Organization. Urbanization: An increasing risk factor for leishmaniasis. Wkly. Epidemiol. Rec. Relev. Épidémiologique Hebd. 2002, 77, 365-370.

4. Pearson, R.D.; Sousa, A.Q. Clinical spectrum of leishmaniasis. Clin Infect Dis. 1996, 22, 1-11. [CrossRef] [PubMed]

5. Hepburn, N.C. Cutaneous leishmaniasis: Clinical dermatology Review article. Clin. Exp. Dermatol. Clin. Dermatol. 2000, 25, 363-370. [CrossRef] [PubMed]

6. Burza, S.; Croft, S.L.; Boelaert, M. Leishmaniasis. Lancet 2018, 392, 951-970. [CrossRef]

7. McGwire, B.S.; Satoskar, A.R. Leishmaniasis: Clinical syndromes and treatment. Qjm: Int. J. Med. 2014, 107, 7-14. [CrossRef] [PubMed]

8. Scorza, B.M.; Carvalho, E.M.; Wilson, M.E. Cutaneous Manifestations of Human and Murine Leishmaniasis. Int. J. Mol. Sci. 2017, 18, 1296. [CrossRef]

9. Bi, K.; Chen, Y.; Zhao, S.; Kuang, Y.; Wu, C.-H.J. Current Visceral Leishmaniasis Research: A Research Review to Inspire Future Study. BioMed Res. Int. 2018, 2018, 1-13. [CrossRef]

10. WHO Expert Committee on the Control of the Leishmaniases. Meeting, World Health Organization. In Proceedings of the Control of the Leishmaniases: Report of a Meeting of the WHO Expert Committee on the Control of Leishmaniases, Geneva, Switzerland, 22-26 March 2010; World Health Organization: Copenhagen, Denmark, 2010.

11. Monzote, L. Current treatment of leishmaniasis: A review. Open Antimicrob. Agents J. 2009, 1, 9-19. [CrossRef]

12. Santos, D.O.; Coutinho, C.E.R.; Madeira, M.F.; Bottino, C.G.; Vieira, R.T.; Nascimento, S.B.; Bernardino, A.; Bourguignon, S.C.; Corte-Real, S.; Pinho, R.T.; et al. Leishmaniasis treatment-a challenge that remains: A review. Parasitol. Res. 2008, 103, 1-10. [CrossRef] [PubMed]

13. Oliveira, L.F.; Schubach, A.O.; Martins, M.M.; Passos, S.L.; Oliveira, R.V.; Marzochi, M.C.; Andrade, C.A. Systematic review of the adverse effects of cutaneous leishmaniasis treatment in the New World. Acta Trop. 2011, 118, 87-96. [CrossRef]

14. Naveed, M.; Phil, L.; Sohail, M.; Hasnat, M.; Baig, M.M.F.A.; Ihsan, A.U.; Shumzaid, M.; Kakar, M.U.; Khan, T.M.; Akabar, M.D.; et al. Chitosan oligosaccharide (COS): An overview. Int. J. Biol. Macromol. 2019, 129, 827-843. [CrossRef] [PubMed]

15. Younes, I.; Rinaudo, M. Chitin and Chitosan Preparation from Marine Sources. Structure, Properties and Applications. Mar. Drugs 2015, 13, 1133-1174. [CrossRef]

16. Muxika, A.; Etxabide, A.; Uranga, J.; Guerrero, P.; de la Caba, K. Chitosan as a bioactive polymer: Processing, properties and applications. Int. J. Biol. Macromol. 2017, 105, 1358-1368. [CrossRef]

17. Wang, W.; Meng, Q.; Li, Q.; Liu, J.; Zhou, M.; Jin, Z.; Zhao, K. Chitosan Derivatives and Their Application in Biomedicine. Int. J. Mol. Sci. 2020, 21, 487. [CrossRef] [PubMed]

18. Ahmed, T.A.; Aljaeid, B.M. Preparation, characterization, and potential application of chitosan, chitosan derivatives, and chitosan metal nanoparticles in pharmaceutical drug delivery. Drug Des. Dev. Ther. 2016, 10, 483-507. [CrossRef] [PubMed]

19. Kravanja, G.; Primožič, M.; Knez, Ž.; Leitgeb, M. Chitosan-Based (Nano)Materials for Novel Biomedical Applications. Molecules 2019, 24, 1960. [CrossRef]

20. Rizeq, B.R.; Younes, N.N.; Rasool, K.; Nasrallah, G.K. Synthesis, Bioapplications, and Toxicity Evaluation of Chitosan-Based Nanoparticles. Int. J. Mol. Sci. 2019, 20, 5776. [CrossRef]

21. Guan, G.; Azad, A.K.; Lin, Y.; Kim, S.W.; Tian, Y.; Liu, G.; Wang, H. Biological Effects and Applications of Chitosan and Chito-Oligosaccharides. Front. Physiol. 2019, 10, 516. [CrossRef] [PubMed]

22. Rozman, N.A.S.; Tong, W.Y.; Leong, C.R.; Tan, W.N.; Hasanolbasori, M.A.; Abdullah, S.Z. Potential Antimicrobial Applications of Chitosan Nanoparticles (ChNP). J. Microbiol. Biotechnol. 2019, 29, 1009-1013. [CrossRef] [PubMed]

23. Rabea, E.I.; Badawy, M.E.; Stevens, C.V.; Smagghe, G.; Steurbaut, W. Chitosan as antimicrobial agent: Applications and mode of action. Biomacromolecules 2003, 4, 1457-1465. [CrossRef]

24. Varshosaz, J.; Arbabi, B.; Pestehchian, N.; Saberi, S.; Delavari, M. Chitosan-titanium dioxide-glucantime nanoassemblies effects on promastigote and amastigote of Leishmania major. Int. J. Biol. Macromol. 2018, 107, 212-221. [CrossRef]

25. Mammeri, M.; Chevillot, A.; Thomas, M.; Polack, B.; Julien, C.; Marden, J.-P.; Auclair, E.; Vallée, I.; Adjou, K.T. Efficacy of chitosan, a natural polysaccharide, against Cryptosporidium parvum in vitro and in vivo in neonatal mice. Exp. Parasitol. 2018, 194, 1-8. [CrossRef]

26. Torabi, N.; Dobakhti, F.; Faghihzadeh, S.; Haniloo, A. In vitro and in vivo effects of chitosan-praziquantel and chitosanalbendazole nanoparticles on Echinococcus granulosus Metacestodes. Parasitol. Res. 2018, 117, 2015-2023. [CrossRef]

27. Teimouri, A.; Azami, S.J.; Keshavarz, H.; Esmaeili, F.; Alimi, R.; Mavi, S.A.; Shojaee, S. Anti-Toxoplasma activity of various molecular weights and concentrations of chitosan nanoparticles on tachyzoites of RH strain. Int. J. Nanomed. 2018, 13, 1341-1351. [CrossRef]

28. Cheraghipour, K.; Masoori, L.; Ezzatkhah, F.; Salimikia, I.; Amiri, S.; Makenali, A.S.; Taherpour, F.; Mahmoudvand, H. Effect of chitosan on Toxoplasma gondii infection: A systematic review. Parasite Epidemiol. Control. 2020, 11, e00189. [CrossRef] [PubMed] 
29. Moher, D.; Liberati, A.; Tetzlaff, J.; Altman, D.G.; Prisma Group. Preferred reporting items for systematic reviews and metaanalyses: The PRISMA statement. Ann. Intern. Med. 2009, 151, 264-269. [CrossRef]

30. Singh, P.K.; Pawar, V.K.; Jaiswal, A.K.; Singh, Y.; Srikanth, C.H.; Chaurasia, M.; Bora, H.K.; Raval, K.; Meher, J.G.; Gayen, J.R.; et al. Chitosan coated PluronicF127 micelles for effective delivery of Amphotericin B in experimental visceral leishmaniasis. Int. J. Biol. Macromol. 2017, 105, 1220-1231. [CrossRef] [PubMed]

31. Mohebali, M.; Esboei, B.R.; Mousavi, P.; Fakhar, M.; Akhoundi, B. Potent antileishmanial activity of chitosan against Iranian strain of Leishmania major (MRHO/IR/75/ER): In vitro and in vivo assay. J. Vector Borne Dis. 2018, 55, 111. [CrossRef]

32. Lima, D.D.S.; Gullon, B.; Cardelle-Cobas, A.; Brito, L.M.; Rodrigues, K.A.F.; Quelemes, P.V.; Ramos-Jesus, J.; Arcanjo, D.D.R.; Plácido, A.; Batziou, K.; et al. Chitosan-based silver nanoparticles: A study of the antibacterial, antileishmanial and cytotoxic effects. J. Bioact. Compat. Polym. 2017, 32, 397-410. [CrossRef]

33. Kunjachan, S.; Gupta, S.; Dwivedi, A.K.; Dube, A.; Chourasia, M.K. Chitosan-based macrophage-mediated drug targeting for the treatment of experimental visceral leishmaniasis. J. Microencapsul. 2011, 28, 301-310. [CrossRef]

34. Tripathi, P.; Jaiswal, A.K.; Dube, A.; Mishra, P.R. Hexadecylphosphocholine (Miltefosine) stabilized chitosan modified Ampholipospheres as prototype co-delivery vehicle for enhanced killing of L. donovani. Int. J. Biol. Macromol. 2017, 105, 625-637. [CrossRef]

35. Karam, T.K.; Ortega, S.; Nakamura, T.U.; Auzély-Velty, R.; Nakamura, C.V. Development of chitosan nanocapsules containing essential oil of Matricaria chamomilla L. for the treatment of cutaneous leishmaniasis. Int. J. Biol. Macromol. 2020, 162, 199-208. [CrossRef] [PubMed]

36. Tripathi, P.; Dwivedi, P.; Khatik, R.; Jaiswal, A.K.; Dube, A.; Shukla, P.; Mishra, P.R. Development of 4-sulfated N -acetyl galactosamine anchored chitosan nanoparticles: A dual strategy for effective management of Leishmaniasis. Colloids Surf. $B$ Biointerfaces 2015, 136, 150-159. [CrossRef] [PubMed]

37. Feizabadi, E.; Zavaran Hosseini, A.; Soudi Sara, K. Studying the role of chitosan nanoparticle loaded with Leishmania major Secretory and excretory antigens on the number of apoptotic macrophages in parasite sensitive mouse. Daneshvar Med. Basic Clin. Res. J. 2020, 26, 9-18.

38. Khan, M.; Shereen, M.A.; Khokhar, M.; Kamil, A.; Rahman, H. A novel effective therapeutic approach for treatment of Leishmania tropica through Miltefosine Loaded Chitosan Nanoparticles. Res. Sq. 2020. [CrossRef]

39. Riezk, A.; Van Bocxlaer, K.; Yardley, V.; Murdan, S.; Croft, S.L. Activity of Amphotericin B-Loaded Chitosan Nanoparticles against Experimental Cutaneous Leishmaniasis. Molecules 2020, 25, 4002. [CrossRef]

40. Rahimi, M.; Tabaei, S.J.S.; Ziai, S.A.; Sadri, M. Anti-Leishmanial Effects of Chitosan-Polyethylene Oxide Nanofibers Containing Berberine: An Applied Model for Leishmania Wound Dressing. Iran. J. Med. Sci. 2020, 45, 286-297.

41. Chaubey, P.; Mishra, B.; Mudavath, S.L.; Patel, R.R.; Chaurasia, S.; Sundar, S.; Suvarna, V.; Monteiro, M. Mannose-conjugated curcumin-chitosan nanoparticles: Efficacy and toxicity assessments against Leishmania donovani. Int. J. Biol. Macromol. 2018, 111, 109-120. [CrossRef]

42. Cabral, F.V.; Pelegrino, M.T.; Sauter, I.P.; Seabra, A.B.; Cortez, M.; Ribeiro, M.S. Nitric oxide-loaded chitosan nanoparticles as an innovative antileishmanial platform. Nitric Oxide-Biol. Chem. 2019, 93, 25-33. [CrossRef] [PubMed]

43. Esfandiari, F.; Motazedian, M.H.; Asgari, Q.; Morowvat, M.H.; Molaei, M.; Heli, H. Paromomycin-loaded mannosylated chitosan nanoparticles: Synthesis, characterization and targeted drug delivery against leishmaniasis. Acta Trop. 2019, 197, 105072 [CrossRef]

44. Seyyed Tabaei, S.J.; Rahimi, M.; Akbaribazm, M.; Ziai, S.A.; Sadri, M.; Shahrokhi, S.R.; Rezaei, M.S. Chitosan-based nano-scaffolds as antileishmanial wound dressing in BALB/c mice treatment: Characterization and design of tissue regeneration. Iran J. Basic Med. Sci. 2020, 23, 788-799.

45. Malli, S.; Pomel, S.; Dennemont, I.; Loiseau, P.M.; Bouchemal, K. Combination of amphotericin B and chitosan platelets for the treatment of experimental cutaneous leishmaniasis: Histological and immunohistochemical examinations. J. Drug Deliv. Sci. Technol. 2019, 50, 34-41. [CrossRef]

46. Malli, S.; Pomel, S.; Ayadi, Y.; Deloménie, C.; Da Costa, A.; Loiseau, P.M.; Bouchemal, K. Topically Applied Chitosan-Coated Poly(isobutylcyanoacrylate) Nanoparticles Are Active Against Cutaneous Leishmaniasis by Accelerating Lesion Healing and Reducing the Parasitic Load. ACS Appl. Bio Mater. 2019, 2, 2573-2586. [CrossRef]

47. Gupta, P.K.; Jaiswal, A.K.; Asthana, S.; Verma, A.; Kumar, V.; Shukla, P.; Dwivedi, P.; Dube, A.; Mishra, P.R. Self Assembled Ionically Sodium Alginate Cross-Linked Amphotericin B Encapsulated Glycol Chitosan Stearate Nanoparticles: Applicability in Better Chemotherapy and Non-Toxic Delivery in Visceral Leishmaniasis. Pharm. Res. 2015, 32, 1727-1740. [CrossRef]

48. Siqueira-Neto, J.L.; Song, O.-R.; Oh, H.; Sohn, J.-H.; Yang, G.; Nam, J.; Jang, J.; Cechetto, J.; Lee, C.B.; Moon, S.; et al. Antileishmanial High-Throughput Drug Screening Reveals Drug Candidates with New Scaffolds. PLoS Negl. Trop. Dis. 2010,4 , e675. [CrossRef]

49. Sharlow, E.R.; Close, D.; Shun, T.; Leimgruber, S.; Reed, R.; Mustata, G.; Wipf, P.; Johnson, J.; O’Neil, M.; Grogl, M.; et al. Identification of Potent Chemotypes Targeting Leishmania major Using a High-Throughput, Low-Stringency, Computationally Enhanced, Small Molecule Screen. PLoS Negl. Trop. Dis. 2009, 3, e540. [CrossRef]

50. St George, S.; Bishop, J.V.; Titus, R.G.; Selitrennikoff, C.P. Novel compounds active against Leishmania major. Antimicrob. Agents Chemother. 2006, 50, 474-479. [CrossRef] 
51. Fumarola, L.; Spinelli, R.; Brandonisio, O. In vitro assays for evaluation of drug activity against Leishmania spp. Res. Microbiol. 2004, 155, 224-230. [CrossRef]

52. De Muylder, G.; Ang, K.K.; Chen, S.; Arkin, M.R.; Engel, J.C.; McKerrow, J.H. A screen against Leishmania intracellular amastigotes: Comparison to a promastigote screen and identification of a host cell-specific hit. PLoS Negl. Trop. Dis. 2011, 5, e1253. [CrossRef]

53. Vermeersch, M.; Da Luz, R.I.; Toté, K.; Timmermans, J.-P.; Cos, P.; Maes, L. In Vitro Susceptibilities of Leishmania donovani Promastigote and Amastigote Stages to Antileishmanial Reference Drugs: Practical Relevance of Stage-Specific Differences. Antimicrob. Agents Chemother. 2009, 53, 3855-3859. [CrossRef]

54. Ribeiro, T.G.; Franca, J.R.; Fuscaldi, L.L.; Santos, M.L.; Duarte, M.C.; Lage, P.S.; Martins, V.T.; Costa, L.E.; Fernandes, S.O.; Cardoso, V.N.; et al. An optimized nanoparticle delivery system based on chitosan and chondroitin sulfate molecules reduces the toxicity of amphotericin B and is effective in treating tegumentary leishmaniasis. Int. J. Nanomed. 2014, 9, 5341-5353.

55. Asthana, S.; Jaiswal, A.K.; Gupta, P.K.; Pawar, V.K.; Dube, A.; Chourasia, M.K. Immunoadjuvant Chemotherapy of Visceral Leishmaniasis in Hamsters Using Amphotericin B-Encapsulated Nanoemulsion Template-Based Chitosan Nanocapsules. Antimicrob. Agents Chemother. 2013, 57, 1714-1722. [CrossRef] [PubMed]

56. Mohammadi-Samani, S.; Bahraini, D.; Shokri, J.; Kamali-Sarvestani, E.; Baezegar-Jalali, M.; Samiei, A.; Danesh-Bahreini, M.A.; Barzegar-Jalali, M. Nanovaccine for leishmaniasis: Preparation of chitosan nanoparticles containing Leishmania superoxide dismutase and evaluation of its immunogenicity in BALB/c mice. Int. J. Nanomed. 2011, 6, 835-842. [CrossRef]

57. Mehrizi, T.Z.; Ardestani, M.S.; Hoseini, M.H.M.; Khamesipour, A.; Mosaffa, N.; Ramezani, A. Novel nano-sized chitosan amphotericin B formulation with considerable improvement against Leishmania major. Nanomedicine 2018, 13, 3129-3147. [CrossRef]

58. Moreno, E.; Schwartz, J.; Larrea, E.; Conde, I.; Font, M.; Sanmartín, C.; Irache, J.M.; Espuelas, S. Assessment of $\beta$-lapachone loaded in lecithin-chitosan nanoparticles for the topical treatment of cutaneous leishmaniasis in L. major infected BALB/c mice. Nanomed. Nanotechnol. Biol. Med. 2015, 11, 2003-2012. [CrossRef]

59. Mehrizi, T.Z.; Ardestani, M.S.; Hoseini, M.H.M.; Khamesipour, A.; Mosaffa, N.; Ramezani, A. Novel Nanosized Chitosan-Betulinic Acid Against Resistant Leishmania Major and First Clinical Observation of such parasite in Kidney. Sci. Rep. 2018, 8, 11759. [CrossRef] [PubMed]

60. Serrano, D.R.; Lalatsa, A.; Dea-Ayuela, M.A.; Bilbao-Ramos, P.E.; Garrett, N.L.; Moger, J.; Guarro, J.; Capilla, J.; Ballesteros, M.P.; Schätzlein, A.G.; et al. Oral Particle Uptake and Organ Targeting Drives the Activity of Amphotericin B Nanoparticles. Mol. Pharm. 2015, 12, 420-431. [CrossRef]

61. Nagy, A.; Harrison, A.; Sabbani, S.; Munson Jr, R.S.; Dutta, P.K.; Waldman, W.J. Silver nanoparticles embedded in zeolite membranes: Release of silver ions and mechanism of antibacterial action. Int. J. Nanomed. 2011, 6, 1833.

62. Suman Gupta, N. Visceral leishmaniasis: Experimental models for drug discovery. Indian J. Med. Res. 2011, 133, 27-39. [PubMed]

63. Li, J.; Cai, C.; Li, J.; Li, J.; Li, J.; Sun, T.; Wang, L.; Wu, H.; Yu, G. Chitosan-based nanomaterials for drug delivery. Molecules 2018, 23, 2661. [CrossRef] [PubMed] 